\title{
Research on the Entrepreneurship Curriculum Design for Art and Design Classes under the Perspective and Guidance of Cultural Creativity and Mass Entrepreneurship
}

\author{
Chen $\mathrm{Wei}^{1}$ \\ ${ }^{1}$ Nanchang media, Career Academy, Jiangxi, \\ Jiangxi Province 330224 China
}

\begin{abstract}
In this paper, we conduct research on the entrepreneurship curriculum design for art and design classes under the perspective and guidance of cultural creativity and mass entrepreneurship. Art design teaching is a multidisciplinary comprehensive knowledge, in the present teaching, professional class teacher can't use more scientific teaching method makes students contact with the market earlier. In China's popularization of higher education has realized the today, the study of entrepreneurship education and in-depth development of entrepreneurship education will bring profound changes to our country's higher education. Our research conduct in-depth analysis on the mentions issues which will has specific meanings and functions.
\end{abstract}

Keywords: Curriculum Design; Art and Design; Mass Entrepreneurship; Cultural Creativity.

\section{Introduction}

Entrepreneurship is a complex process, entrepreneurial process need to involve economics, management, psychology, law, accounting, advertising and other aspects of knowledge. Knowledge of economics can make entrepreneurs in creating some economic relations, or in economic transformation period, using the theory of economics and law, realize the small investment, quick, high growth accumulation. Startup also need to know some relevant laws and regulations, such as product quality law, labor contract law, safety production law, intellectual property law, etc., in order to avoid unnecessary trouble. After established new companies, entrepreneurs can through effective management, make the enterprise become a vibrant entrepreneurial organization, make limited resources to maximum effect. The complexity of the entrepreneurial process and the diversity of knowledge determine the business has the characteristics of comprehensive course. Innovation entrepreneurship courses determines the nature of innovation and entrepreneurship is in course of righteousness, spirit and goals to pursue, the innovative spirit as the core of quality education, innovative mechanism as the core of methodology, self-employment ability as the core aspect of development work function and practical ability as the core of executive function is the basic function of innovation in entrepreneurship. Entrepreneurship education is gradually becoming the hot spot of the education teaching reform in colleges and universities in our country, many schools are actively explore the entrepreneurial talent training mode reform. But must see, entrepreneurial talent training is still at groping stage in our country, should establish the concept of education, undertake what kind of talent training task and how to train and other issues are still need further exploration and practice.

Art design teaching is a multi-disciplinary comprehensive knowledge, in the present teaching, professional class teacher can't use more scientific teaching method makes students contact with the market earlier, course setting is difficult to combine relatively new design concept, to have a purpose, the targeted teaching. It is not a simple teaching reform at the heart of 
the pursuit of the project: let the students according to the arrangement of the teachers and teaching to the results, but under the guidance of teachers, let the students to look for ways to get the result, finally get the results, and to display and self-evaluation. Study is focused on the learning process and they can exercise all kinds of ability in the process. The teacher teaching process is not dominant, and becoming the leader of students learning process, directors and supervisors, students have a higher enthusiasm.

Project with entrepreneurship teaching mode can be divided into specific aspects as follows. (1) Project teaching mainly refers to the students the use of certain operating tools and methods to solve tasks faced by the study of action. In the project teaching, students are not passively accepting the teacher in the classroom knowledge transfer, but focuses on the practice, the knowledge and skills in the process of completing the task. (2) Project teaching based on the real working process, curriculum resources, and its main content from the real work situation of the typical professional task, content should be and enterprise actual production process is directly related to business or reality. (3) Situation refers to support the student to carry on the inquiry learning environment. This kind of environment can be a real working environment, can also be the conditions with the aid of information technology of the virtual environment simulation or work environment [1]. (4) Result means that in the process of learning or at the end of the study, the students have learned through exploring action of professional knowledge, professional skills and professional attitudes such as the technical know-how, cooperation ability, innovative ability, and so on.

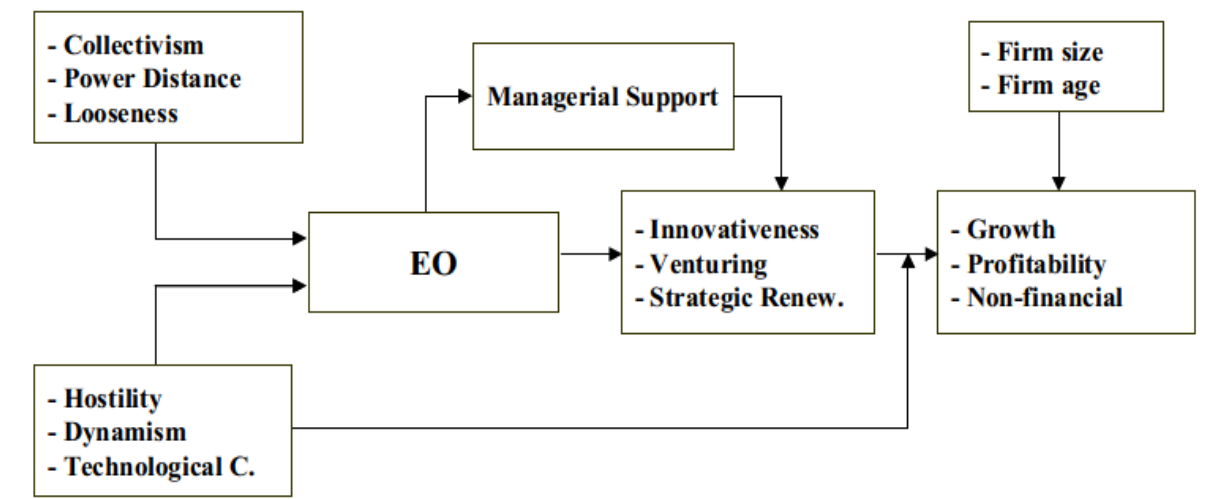

Figure 1. The Basic Component for Entrepreneurship Curriculum Design

In this paper, we conduct research on the entrepreneurship curriculum design for art and design classes under the perspective and guidance of cultural creativity and mass entrepreneurship. Entrepreneurship education and entrepreneurial support system in colleges and universities is not only the important way to alleviate the pressure of the college students' employment is also related to higher education personnel training mode and how to optimize the allocation of resources of colleges and universities, for the future of our country's higher education reform and development is of great significance. In the figure one, we illustrate the component for entrepreneurship curriculum design.

\section{The Proposed Methodology and Novel Perspective}

The Concepts of Mass Entrepreneurship. To promote college students' innovative undertaking education is not only the objective needs of the development of university itself, is also China's economic and social development of college education put forward the urgent request. Effectively to carry out the practice education in college students, to cultivate 
students' interest in social practice and stimulating the enthusiasm of entrepreneurship, help students to establish correct to not social socialist outlook on life and values, to promote college students' personal development and the improvement of comprehensive ability. In China's popularization of higher education has realized the today, the study of entrepreneurship education and in-depth development of entrepreneurship education will bring profound changes to our country's higher education, the concept and practice of entrepreneurship education is helpful to our country's higher education should change the huge internal and external environment, is under the background of globalization and the new industrialization of our country's higher education development orientation of major adjustment.

Training qualified teachers in colleges and universities in the entrepreneurship education will change the idea, to guide the most talented students to become entrepreneurs, so as to realize the optimal allocation of human resources. A society, most people can choose what kind of career will have a great influence on the allocation of resources. When talented people become entrepreneurs, they will improve their engaged in by the department of technology, production efficiency and income. Entrepreneurship education for college students' self-employment provides a solid support, will create a more broad space for development to university students. Through the system of entrepreneurship education, college students for the choice of entrepreneurial projects, the pioneering plan, policy, and the pioneering program, possible problems and challenges in the process, for their own interests and professional, will have the profound understanding. Innovation entrepreneurship education in our country is now in full swing, the goal of colleges and universities is to create a mutually inclusive education method, and makes student, school and society benefit the sustainable development of the unified model of education. Through entrepreneurship education, college students' self-positioning will be more accurate, to learn professional knowledge will be more active, the combination of theory and practice will be more closely. This not only make the employment pressure of college students a chance to choose more, also can make ready for college students to improve success rate of entrepreneurship, for college students' future career. From a macroeconomic perspective, under the condition of increasing pressure of employment and the entrepreneurship education to create new avenues of employment is of great significance.

The Cultural Creativity and Drawback of Current Education Model. Institutions of higher learning in are a planned way to cultivate students pioneering spirit and improve their ability of organization as a series of education teaching activities. The author thinks that entrepreneurship refers to colleges and universities to cultivate college students' entrepreneurship and entrepreneurial ideas which make it possess the innovation ability of education and teaching activities. College students' entrepreneurship curriculum construction is mainly refers to in order to realize the goal of entrepreneurship education in colleges and universities, to the various elements of entrepreneurship curriculum system construction and optimization of management process [2-3].

However, our current education model has some drawbacks which could be summarized as the follows. (1) The severe lack of qualified teachers. Due to the characteristics of college students' entrepreneurship has strong practicality, in the construction of teachers team, institutions in such aspects as curriculum development, practice activity and must have a high quality teaching resources as the support. Especially college students entrepreneurship to teacher's comprehensive quality request is higher, the basic knowledge also have certain experience of entrepreneurship education in an all-round way. This kind of high quality business courses lack of professional teachers. (2) Lack of necessary 
practicality and operability. College students' entrepreneurship is based on practice, the basic features of the course teaching content and teaching mode should be different from theory courses, requires a lot of practice of consideration and support. However, most of entrepreneurship curriculum of practical activity resources of colleges and universities in our country, often by some enterprises and relevant experts to lecture and means of communication for the practice of entrepreneurship, therefore, less practical operability. (3) The lack of scientific entrepreneurship education concept. As things look, though, the construction of the college students' entrepreneurship in has received the unprecedented attention, but the concept of entrepreneurship for college students, the teaching goal, teaching method is lack of scientific and advanced education concept. Some schools equating entrepreneurship to improve students' employment course of employment, some schools equating entrepreneurship to cultivate entrepreneurial elite education courses. Overall speaking, college students' entrepreneurship curriculum system and training goal of the lack of a clear set of making college students entrepreneurship material is not strong, technology content is not high, can't be positive teaching effect of college students' entrepreneurship. (4) Lack of systemic and perfection of curriculum system. At present, the existing problems in college students' general entrepreneurship is the lack of systemic and perfection of curriculum system and some of the schools entrepreneurship no specialized courses and required courses, in the form of elective courses.

The Modification of the Entrepreneurship Curriculum Design. Although entrepreneurship in business, but should not be narrowly as mere business practices. As thinking, reasoning and unique mode of action, entrepreneurial needs imagination, insight, and creative ability to integrate resources, therefore, in a broader sense, the transformation form of entrepreneurship is a kind of innovation, is to start a new career.
Based on the point of view, entrepreneurial talent is to point to in pioneering work or career thinking, good at innovation, creativity and management skills, regardless of the future will start a business. Entrepreneurial talent training goal is to cultivate the entrepreneurial quality of teachers, including the pioneering consciousness, psychological quality, entrepreneurial knowledge and entrepreneurial ability, in order to better adapt to the requirements of the job, adapt to social change. Entrepreneurship is a practical work. This means that in the process of entrepreneurship education and just simply teaches business knowledge and relevant skills are not enough. Should practice teach is an important link in entrepreneurship, the missing link, it can make college students in the process of entrepreneurship theory. Our suggestions could be summarized as the follows. (1) Entrepreneurship education combined with professional education. The current courses in business for more public elective courses in colleges and universities, and the characteristics of public course is course is numerous, class size. Such result, too many students in the process of the class, the teacher control the class difficult, causing the teaching effect is affected. (2) Use the participatory teaching method. Constructivism teaching view believes that the subjectivity of students is of natural, rather than the outside world, given by the students is the construction of their knowledge, learning is learners on the basis of the original knowledge, actively constructing internal mental representation and the significance of the new knowledge. In view of this, entrepreneurship teachers should pay attention to the diversification of the participatory teaching method which let students really into the classroom, the greatest extent stimulate students' interest and learning motivation, so as to grasp the essence of the theory. (3) Building innovative entrepreneurship education multistage structure. In order to guarantee the standardization of the innovation of colleges and universities entrepreneurship education and 
continued development, should set up university innovation entrepreneurship education multilevel structure, established at the field level school innovative entrepreneurial management center, established at the school level and professional level of innovation in a number of disciplines or professional practice base, in the aspect of students association organized students to set up all kinds of innovative entrepreneurial practice. (4) Makes the corresponding the practice teaching platform. Entrepreneurship practicality characteristic determines the entrepreneurial talent training must be extended to the entrepreneurial practice teaching platform, through the necessary practice help teachers to cultivate entrepreneurial quality and entrepreneurial ability. Co-operative is creating entrepreneurial talent training is an effective means of practical teaching platform. We firmly believe that through the reform, the performance of the classes will be enhanced.

\section{CONCLUSIONS}

In this paper, we conduct research on the entrepreneurship curriculum design for art and design classes under the perspective and guidance of cultural creativity and mass entrepreneurship. Colleges and universities how to definite target in entrepreneurship and to strengthen the construction of entrepreneurship to enhance the innovation ability of students is worth thinking about the problem of universities and even the whole society is important. This paper analyzes the connotation of entrepreneurship in the college students, analyzes the current situation and existing problems of the construction of the college students' entrepreneurship, and countermeasures for the construction of entrepreneurship for college students has carried on the deep discussion. Our method will enhance and optimize the current education model which will be meaningful.

\section{References}

[1] Godley A C. Creativity and Growth in: Edmund Phelps (2013), Mass Flourishing. How Grassroots Innovation Created Jobs, Challenge and Change[J]. International Journal of the Economics of Business, 2014, 21(2):255-260.

[2] Campopiano G, Massis A D, Cassia L. Corporate Social Responsibility in Family Versus Non-Family Enterprises: An Exploratory Study[J]. International Studies in Entrepreneurship, 2014.

[3] Roed K, Skogstr03m J. Job Loss and Entrepreneurship[J]. Social Science Electronic Publishing, 2014. 